3. Обозначение ветвей «2-го уровня», обозначение на стрелках характера их связей с ветвями «1-го уровня»;

4. Использование цвета для дифференциации связей;

5. Применение символов, иконок, рисунков, условных обозначений;

6. При необходимости добавляется индивидуальная краткая характеристика персонажей.

В качестве примера рассмотрим краткое содержание рассказа И.С. Тургенева «Муму», входящий в курс литературы 5 класса по программе Г.И. Беленького[3].

Центральный образ - Герасим. Ветви «1-го уровня»: Барыня (подчинение), прачка Татьяна (взаимное чувство), Муму (забота, привязанность). Ветви «2-го уровня»: Гаврила (+Барыня - подчинение), башмачник Капитон (+Татьяна - брак против воли).

Таким образом, работа по оформлению краткого содержания художественного произведения в виде интеллект-карты одновременно решает следующие задачи:

- сокращение объёма фиксируемого материала;

- формирование навыка литературного анализа;

- формирование у обучающихся умения работать со схемами, прослеживать причинно-следственные связи; давать краткую характеристику героям и др.

Список литературы:

1. Каверзина А.В. Технология «интеллект-карт» http://nsportal.ru/shkola/mezhdistsiplinarnoe-obobshchenie/library/2016/09/23/tehnologiyaintellekt-kart

2. Филиппова Е.К. Технология применения интеллект-карт на уроках русской литературы. http://www.myshared.ru/slide/368445/

3. Беленький Г.И., Снежневская М.А. Литература. Начальный курс 5 класс. Учебник-хрестоматия: в 2-х частях. - М.: Мнемозина, 2016.

\title{
Типичные речевые ошибки гимназистов
}

Мельниченко И., Собашникова А., Ивлева А., учащиеся, МОУ Гимназия №1, г. Нерюнгри

Научный руководитель: учитель русского языка и литературы Бушман Е.A.

Иван Сергеевич Тургенев справедливо называл русский язык «великим и могучим».

Однако речь наших сверстников становится всё более безграмотной. Конечно, наш язык изменяется не без причины. Исследуя речевые ошибки гимназистов, мы предположили, что анализируя и классифицируя речевые ошибки, допущенные сверстниками в устной и письменной речи, можно повысить собственную речевую культуру.

Цель нашей работы: проанализировать состояние речевой культуры гимназистов установить её соответствие современным лексическим и морфологическим нормам. 
Достижение поставленной цели требует решения следующих задач:

1) Изучить теоретический материал, классифицировать ошибки

2) Отобрать из устной речи гимназистов речевые фрагменты, в которых допущены ошибки

Объектом исследования стала речь, звучащая в гимназии. Предмет исследования, соответственно, - речевые ошибки гимназистов.

Методы исследования: Изучение литературных источников, интернет - ресурсов, анкетирование, анализ речи учеников, классификация выявленных ошибок.

Проведённые нами исследования позволили нам классифицировать типичные ошибки наших одноклассников. В основном, это лексические и морфологические ошибки.

Первое микроисследование мы провели, анализируя ошибки, допущенные гимназистами в сочинениях. Тетради были предоставлены нашим учителем Бушман Еленой Анатольевной. Всего нами было выявлено 17 ошибок, связанных с лексической несочетаемостью, неверным употреблением фразеологизмов, а также неправильным пониманием значения слова.

Лексика - это словарный запас языка. Ошибки возникают тогда, когда мы плохо знаем правила сочетаемости слов, мало читаем, имеем скудный словарный запас.

Мы повышаем свой кругозор. (РАСШИРЯЕМ)

Он сидел в раздумьях. (НАХОДИЛСЯ)

Доброта находит отражение в сердцах людей. (ОТКЛИК)

Люди не делают добрых поступков. (НЕ СОВЕРШАЮТ)

Такт и великодушие - одни из самых важных качеств. (САМЫЕ ВАЖНЫЕ)

Он показывает свои лучшие качества. (ПРОЯВЛЯЕТ)

Решил пойти на помощь (ПОМОЧЬ)

Зачастую ребята допускают ошибки в употреблении фразеологизмов устойчивых словосочетаний, в составе которых ничего нельзя менять, иначе фразеологизм разрушится (см. Фразеологический словарь русского языка, Словарь крылатых выражений, пословиц и поговорок). Мы обнаружили следующие недочёты:

Он ведёт хорошо (ВЕДЁТ СЕБЯ)

Набить карман больше (ТУЖЕ)

Одержать поражение (ПОТЕРПЕТЬ ПОРАЖЕНИЕ)

Многие из ребят нашей гимназии неверно истолковывают значение отдельных слов.

Приведённые примеры найдены в письменных работах учеников 6 и 9 классов.

Чистолюбивая девочка (ЧИСТОПЛОТНАЯ)

Чиноприкладство (ЧИНОПОЧИТАНИЕ или РУКОПРИКЛАДСТВО)

Очковтирательство - протирание штанов (ОБМАН)

Немало речевых ошибок можно отметить и в устной речи ребят. Самая распространённая ошибка связана с употреблением паронимов - однокоренных слов, которые относятся к одной части речи, близки по звучанию и значению, но имеют различия

в звучании,

в значении,

в лексической сочетаемости.

В нашем случае это паронимы «надеть» и «одеть». Подавляющее большинство ребят говорят «я одену пальто» вместо «я надену». Другой пример связан со словами 
«оплатить» - «заплатить». «Я оплатил за булочку» - такую фразу нам довелось услышать в нашей школьной столовой.

Рассмотрим морфологические ошибки.

Морфологией называют раздел лингвистики, в котором изучаются слова и их части. Морфологические ошибки получаются из-за неправильного образования форм слов различных частей речи. Причинами являются неправильное склонение, ошибки в употреблении рода и числа.

Чаще других частей речи, на наш взгляд, искажаются имена числительные. Мы провели небольшое исследование, предложив 30 ребятам нашей параллели написать словами следующие выражения:

в 2017 году

с 50 рублями

на (оба, обе) подруг можно положиться

обратиться к 200 слушателям.

Вот что мы получили.

В двухтысячносемнадцатом году-13 человек

С пятидесятью рублями- 8человек

На обоих подруг можно положиться-7человек

Обратиться к двухстам слушателям-12человек

Следующая морфологическая ошибка связана с употреблением форм глаголов.

В речи гимназистов разного возраста зафиксировано достаточно много таких недочётов:

ЛожИть на стол (КЛАСТЬ)Это слово - чемпион по частоте употребления! Есть ещё замечательный вариант - лОжить!!

Повешаю на место (ПОВЕШУ)

Склади учебники (СЛОЖИ)

Накласть в тарелку (НАЛОЖИТЬ)

Поженился на ней (ЖЕНИЛСЯ)

Махают руками (МАШУТ)

Папа броется утром (БРЕЕТСЯ)

Я убралась в комнате (УБРАЛА)

Отчего речь наших сверстников порой так удручающе безграмотна? Думаем, причин много. Это и не всегда безупречная речевая среда, и недостаточный интерес к чтению, и нежелание заниматься самообразованием. Проводя свои исследования, мы узнали много нового и, безусловно, повысили свою речевую культуру. Русский язык поистине неисчерпаем!

«В шесть лет можно выучиться всем главным языкам, но всю жизнь надобно учиться своему природному». Н.М. Карамзин

Список литературы: 2014.

1. Ларионова Ю.А. Фразеологический словарь современного русского языка. М.,

2. Савко И. Э. Русский язык. Правильность речи. М., 2008.

3. Словарь пословиц, поговорок и крылатых выражений. М., 2011.

4. Фоменко Ю.В. Типы речевых ошибок. Новосибирск, НГПУ, 1994. 